\title{
Evolution Trends of Facebook Marketing in Digital Economics Growth: A Bibliometric Analysis
}

\author{
https://doi.org/10.3991/ijim.v15i20.23741 \\ Nadzrif Othman ${ }^{1}$, Norbayah Mohd Suki ${ }^{2(凶)}$, Norazah Mohd Suki ${ }^{3}$ \\ ${ }^{1}$ Universiti Utara Malaysia, Kedah, Malaysia \\ ${ }^{2}$ Universiti Utara Malaysia, Sintok, Malaysia \\ ${ }^{3}$ Universiti Utara Malaysia, Kuala Lumpur, Malaysia \\ bayasuki@yahoo.com
}

\begin{abstract}
Facebook, a form of digital marketing tool acts as a valuable element to reach out to the people or potential communities which aids in generating millions of revenues for businesses. Facebook Marketing has become one of the famous online marketing tools besides Google Advertisement. Many businesses ranging from Small Medium Enterprises (SME) to large scale corporations rely on Facebook Marketing because the results yielded are extensively and impeccably lucrative for these businesses. This study aims to provide an overview of literature on Facebook Marketing for the years ranging between 2006 and 2020 by using bibliometric analysis of research productivity viewed through Scopus database. The analysis captured the most influential document and source types during this period. It also captured the most significant countries who contributed to the publications, the most productive authors and the most noticeable institutions involved with the related documents. The main method used was searching within the Scopus database, Visualisation of Similarities (VOSviewer) software and Harzing's Perish software. The results of the analysis revealed that of the 1888 document source type, Journal is the preferred source type for publication with $66.21 \%$ (1250 sources). This is followed by Conference Proceeding with $21.21 \%$ (408 sources), Book Series covers 5.93\% (112 sources), Book covers $5.24 \%$ (99 sources), and Trade Journal covers 1.01\% (19 sources).
\end{abstract}

Keywords - facebook, marketing, scopus, bibliometric analysis

\section{Introduction}

With software and hardware progression, Internet connects computers all around the globe. This highly sophisticated environment has brought the communications aspects to a greater level. With this high level of communication, social media appears gradually to simplify communication between people [1-3]. Facebook had billion of subscribers who share their personal information background whereby theycan chat on and search for new friends [4, 5]. Facebook algorithm changes and improves of which there are many interactive tools have been introduced in Facebook and one of the 
most lucrative tools is Facebook Advertisement. This Facebook Advertisement implied towards the study of Facebook Marketing. Facebook Marketing has been determined as a way of e-marketing that strategically enhances business to consumers in a widespread matter [6]. With billions of Facebook accounts that can be targeted strategically by concentrating on certain scope or areas, using Facebook Marketing is more lucrative than doing traditional marketing by distributing flyers or leaflets, face to face. Accordingly, more research on its trends is deemed necessary. Hence, this study aims to provide an overview of literature on Facebook Marketing for the years ranging between 2006 and 2020 by using bibliometric analysis of research productivity viewed through Scopus database.

\section{Literature review}

Facebook Marketing has been dispersing rapidly towards consumer or targeted audiences due to its ability to categorize people or Facebook accounts by dividing them into multiple interests that can be targeted, and each and every niche or businesses has a different set of customers [1-3]. Consequently, Facebook Marketing has the advantages to sort accordingly towards the customer avatar. When the marketing meets the correct and precise set of customer avatar, the marketing can be considered successful. But although it is easier said than done, Facebook Marketing does provide these features that can result in flying colours. Through Facebook Marketing, businesses may anticipate profitability, when their product or service experience viral effects. Even without using paid Facebook Marketing, passive marketing through peer influence and social contagion also may obtain results [7]. This is what brilliance is all about. Even without spending money or making investments, businesses may benefit from the power of Facebook Marketing.

Branding plays a vital role for products to overwhelm potential customers. Before the emergence of social media, traditional media branding was used as awareness campaign throughout the nation. For example, broadcasting through television or radio. These traditional media are said to impact more towards the brand awareness, whereas social media such as Facebook impacted more on brand image [8]. Facebook Marketing does the job for both brand awareness and brand image. For Facebook Marketing, the brand awareness may reflect on the customer's decision in purchasing products. Positive effects of brand awareness through Facebook page does the job quite effectively, with proven results and findings [9]. Without a doubt, Facebook Marketing may represent new marketing opportunities towards businesses worldwide, especially for the type of businesses with a luxurious niche. For example, a luxury fashion brand may find Facebook Marketing as a business take-off tool [6].

As for business-to-business (B2B), Facebook accounts are more effective when they include corporate brand name and avoid "hard sell" commercials [11]. In contrary, "soft sell" commercials would be better to achieve positive results. Engagements in Facebook Marketing will set the businesses either to soar, or just roar without proven results. These engagements can be determined through "Like" and "Comment" buttons in a Facebook page. It is very important for businesses to obtain engagements from their targeted or potential customers. This will help managers of the businesses to effectively 
use their Facebook Marketing tools, as well as equipping their ground work to be more attractive to the targeted or potential customers [12]. Engagements also rely on persuasive messages as an influential marketing method. Messages that are irrelevant and blunt will receive less engagement. With persuasive and relevant messages, liking and sharing them will be more likely to increase the effect of popular cohesion [13].

To achieve greater outcomes, businesses must provide rich and excellent page content for their customers to follow and end up as repetitive buyers. Without excellent content, followers would unfollow the business page in order to search for other reliable similar business. Richness of contents via images, info and videos will lead to beneficial impact [14]. In other words, the richness of contents in the Facebook Marketing would lead towards excellent consumer-brand relationships. For example, restaurants that have extremely good information in their Facebook page would get a strong bonding with their customers. Not only information about their food, menu or prices, but the restaurants can also post mouthwatering recipes to attract their consumers. This is to develop strong trust and commitment towards the brand [15].

With proper evaluation, businesses may apprehend ways to go beyond to be better from their competitors. This is to achieve greater competitive advantages [16]. Besides businesses doing marketing through Facebook, other companies or organisations may also use Facebook Marketing. Distributing valuable information also can be done effectively. For example, during this Covid-19 pandemic, the Malaysian Ministry of Health managed correct information effectively. By using their official Facebook account, various accurate information was distributed daily to the public. This was possible because Facebook has a low-cost rapid transmission through widespread community [17].

The activities in the social media [36, 37], particularly Facebook, such as sharing information, knowledge and participating in discussions reflected the overwhelming results [3, 18]. The impact of Facebook Marketing in Malaysia does improve organizations' performance, in terms of customer service activities, relations and other customer enhancements accomplishments [19]. Nevertheless, Facebook Marketing has given a strong impact on behaviors towards Malaysians as a respectful community that sustains good information at hand.

\section{Methods}

Bibliometric analysis method is used to quantitatively assess journals or authors by statistical approaches such as citation rates [20]. Furthermore, bibliometric analyses publications for quantitative values, for example the number of citations, productive authors and other important values. Bibliometric can be either descriptive or evaluative, such as using citation analysis to look at how those articles influenced subsequent research by others [21]. Scopus, as the world's well-known largest abstract and citation database have extensively thousands of documents and journals from various titles, fields, scopes and international publishers. The wide coverage encompasses areas such as Computer Science, Business, Engineering, Social Sciences, Arts and Humanities, Economics and Psychology.

Figure 1 illustrates the PRISMA flow diagram of the present study by using keywords "Facebook" and "Marketing" i.e. (TITLE-ABS-KEY ("Facebook") AND 
TITLE-ABS-KEY ("Marketing”)). within the Scopus database. The result retrieved 2021 documents. In the 2nd stage, with elimination of undefined features i.e. (TITLEABS-KEY (“Facebook") AND TITLE-ABS-KEY ("Marketing”)) AND (EXCLUDE (AFFILCOUNTRY, “Undefined")) AND (EXCLUDE (PREFNAMEAUID, “Undefined\#Undefined")) AND (EXCLUDE (DOCTYPE , "Undefined")), the result turned out 1888 documents were retrieved. Ensuing to that, Visualisation of Similarities (VOSviewer) software, a computer program for bibliometric mapping was performed together with Harzing's Publish or Perish software.
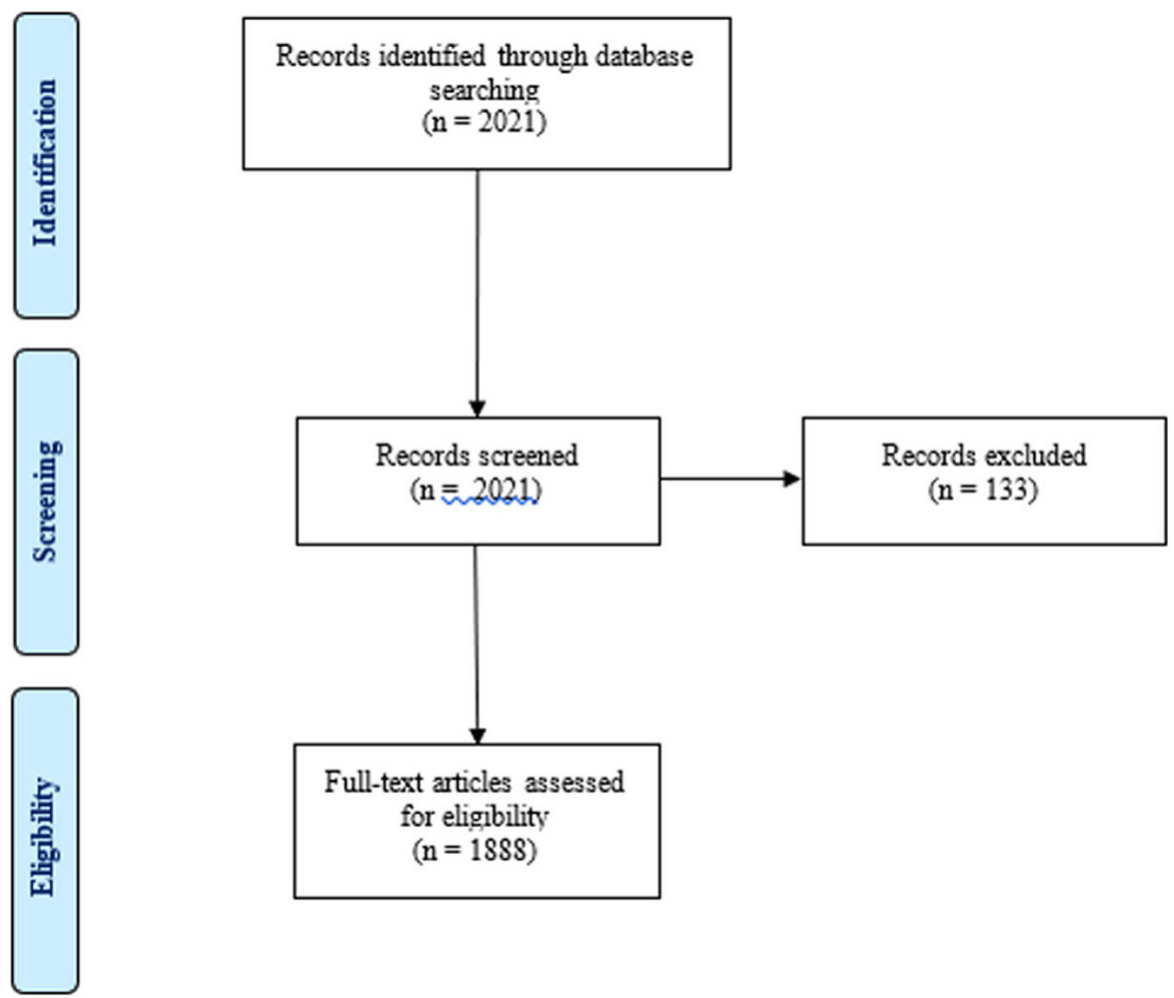

Fig. 1. PRISMA flow diagram

\section{$4 \quad$ Results}

This section presents the result of bibliometric analysis of research publication related to Facebook Marketing derived from the Scopus database. The analysis generates results of document and source types, years of publications, languages of documents, and subject area. In addition, bibliometric data on countries with highest publications, top publishing venues, most influential institutions, keywords analysis, and citation analysis are also furnished. 


\subsection{Document and source types}

Table 1 shows that the queries result consists of 1888 documents. Article comprises 64.3\% (1214 documents), Conference Paper comprises 26.91\% (508 documents), Book Chapter comprises 5.14\% (97 documents), Review comprises 2.28\% (43 documents), Book comprises $0.74 \%$ (14 documents), Short Survey comprises 0.21\% (4 documents), Note comprises $0.16 \%$ (3 documents), Letter comprises $0.11 \%$ (2 documents). Meanwhile Data Paper, Editorial and Erratum comprises $0.05 \%$ for each type with 1 document per type.

Table 1. Document type

\begin{tabular}{|l|c|c|}
\hline \multicolumn{1}{|c|}{ Document Type } & Frequency & $\mathbf{\%}$ (N = 1888) \\
\hline Article & 1214 & 64.3 \\
\hline Conference Paper & 508 & 26.91 \\
\hline Book Chapter & 97 & 5.14 \\
\hline Review & 43 & 2.28 \\
\hline Book & 14 & 0.74 \\
\hline Short Survey & 4 & 0.21 \\
\hline Note & 3 & 0.16 \\
\hline Letter & 2 & 0.11 \\
\hline Data Paper & 1 & 0.05 \\
\hline Editorial & 1 & 0.05 \\
\hline Erratum & 1 & 0.05 \\
\hline Total & $\mathbf{1 8 8 8}$ & $\mathbf{1 0 0 . 0 0}$ \\
\hline
\end{tabular}

Of the 1888 document source type presented in Figure 2, Journal is the preferred source type for publication with $66.21 \%$ (1250 sources). This is followed by Conference Proceeding with 21.21\% (408 sources), Book Series covers 5.93\% (112 sources), Book covers 5.24\% (99 sources), and Trade Journal covers 1.01\% (19 sources).

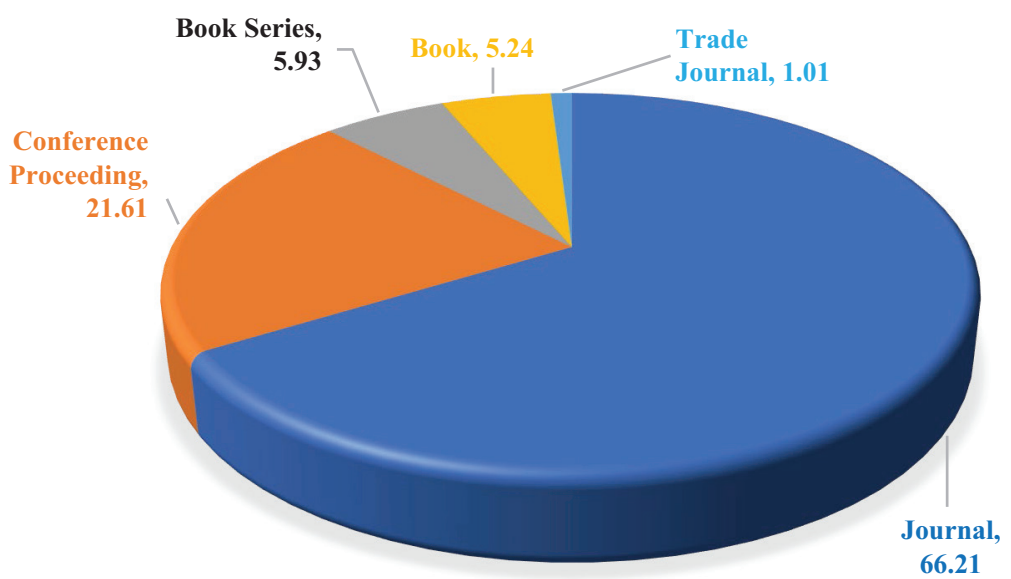

Fig. 2. Document source type 


\subsection{Year of publications}

Number of documents that are analysed from year 2006 to 2020 is graphically illustrated in Figure 3. Bigger portion of publications produced during the year 2019 with $16.21 \%$ and the least during the year 2006 with $0.05 \%$.

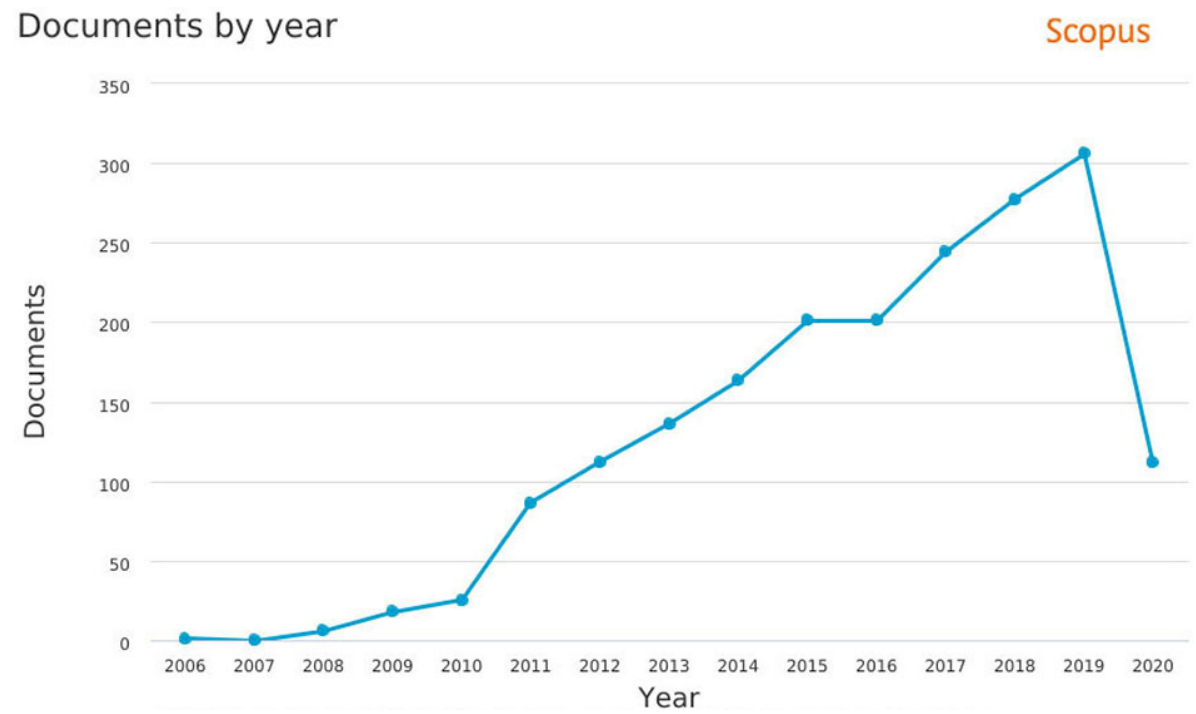

Fig. 3. Document by year

\subsection{Languages of documents}

In regards to language used in publications; English is mainly usedin publications with 97.36\% (1843 publications) (see Table 2). Other languages like Portuguese encompasses $1 \%$ (19 publications), Spanish comprises $0.74 \%$ (14 publications), German comprises $0.32 \%$ (6 publications), French $0.21 \%$ (4 publications), Russian $0.16 \%$ ( 3 publications), Hungarian $0.11 \%$ ( 2 publications) and the least frequent languages used in publications were Czech and Italian, respectively $0.05 \%$ (1 publications) for each of them.

Table 2. Publications categorized by languages

\begin{tabular}{|c|c|c|}
\hline Language & Frequency* & $\%(N=1893)$ \\
\hline English & 1843 & 97.36 \\
\hline Portuguese & 19 & 1 \\
\hline Spanish & 14 & 0.74 \\
\hline German & 6 & 0.32 \\
\hline French & 4 & 0.21 \\
\hline Russian & 3 & 0.16 \\
\hline
\end{tabular}


Table 2. Publications categorized by languages (continued)

\begin{tabular}{|l|c|c|}
\hline \multicolumn{1}{|c|}{ Language } & Frequency* & \% (N= 1893) \\
\hline Hungarian & 2 & 0.11 \\
\hline Czech & 1 & 0.05 \\
\hline Italian & 1 & 0.05 \\
\hline Total & $\mathbf{1 8 9 3}$ & $\mathbf{1 0 0 . 0 0}$ \\
\hline
\end{tabular}

\subsection{Subject area}

Table 3 particulars the subject area for the bibliometric analysis. The highest frequency subject is Computer Science with respectively 23.93\% (775 subject), whereas the lowest frequency subject is Veterinary, comprises of $0.06 \%$ (2 subject).

Table 3. Subject area

\begin{tabular}{|c|c|c|c|c|c|}
\hline Subject Area & Frequency & $\begin{array}{c}\% \\
(\mathrm{~N}=3239)\end{array}$ & Subject Area & Frequency & $\begin{array}{c}\% \\
(\mathrm{~N}=\mathbf{3 2 3 9})\end{array}$ \\
\hline $\begin{array}{l}\text { Agricultural and } \\
\text { Biological }\end{array}$ & 23 & 0.71 & Health Professions & 10 & 0.31 \\
\hline Sciences & & & Immunology and & 5 & 0.15 \\
\hline Arts and Humanities & 87 & 2.69 & Microbiology & & \\
\hline $\begin{array}{l}\text { Biochemistry, Genetics } \\
\text { and }\end{array}$ & 15 & 0.46 & Materials Science & 18 & 0.56 \\
\hline Molecular Biology & & & Mathematics & 131 & 4.04 \\
\hline $\begin{array}{l}\text { Business, Management } \\
\text { and }\end{array}$ & 703 & 21.7 & Medicine & 174 & 5.37 \\
\hline Accounting & & & Multidisciplinary & 15 & 0.46 \\
\hline Chemical Engineering & 10 & 0.31 & Neuroscience & 7 & 0.22 \\
\hline Chemistry & 4 & 0.12 & Nursing & 24 & 0.74 \\
\hline Computer Science & 775 & 23.93 & Pharmacology & 23 & 0.71 \\
\hline Decision Sciences & 144 & 4.45 & Toxicology and & & \\
\hline Dentistry & 3 & 0.09 & Pharmaceutics & & \\
\hline $\begin{array}{l}\text { Earth and Planetary } \\
\text { Sciences }\end{array}$ & 11 & 0.34 & Physics and & 21 & 0.65 \\
\hline $\begin{array}{l}\text { Economics, } \\
\text { Econometrics and }\end{array}$ & 165 & 5.09 & Astronomy & & \\
\hline Finance & & & Psychology & 75 & 2.32 \\
\hline Energy & 30 & 0.93 & Social Sciences & 473 & 14.6 \\
\hline Engineering & 250 & 7.72 & Veterinary & 2 & 0.06 \\
\hline Environmental Science & 41 & 1.27 & & & \\
\hline Total & 3239 & 100 & Total & 3239 & 100 \\
\hline
\end{tabular}




\subsection{Most active source titles}

The top 20 most active source title as shown in Table 4 details that Lecture Notes in Computer Science Including Subseries Lecture Notes in Artificial Intelligence and Lecture Notes in Bioinformatics leads the list. The second most active source title is ACM International Conference Proceeding Series, with 3.14\% (27 No. of Documents).

Table 4. Top 20 active publishing

\begin{tabular}{|c|c|c|}
\hline Source Title & No. of Documents & $\%$ \\
\hline $\begin{array}{l}\text { "Lecture Notes in Computer Science Including Subseries Lecture Notes } \\
\text { In Artificial Intelligence and Lecture Notes in Bioinformatics" }\end{array}$ & 34 & 3.95 \\
\hline "ACM International Conference Proceeding Series" & 27 & 3.14 \\
\hline "Computers in Human Behavior" & 22 & 2.56 \\
\hline "Advances in Intelligent Systems And Computing" & 20 & 2.32 \\
\hline "Journal of Research In Interactive Marketing" & 20 & 2.32 \\
\hline "Journal of Medical Internet Research" & 18 & 2.09 \\
\hline "Communications in Computer and Information Science" & 16 & 1.86 \\
\hline "Journal of Business Research" & 16 & 1.86 \\
\hline "Business Horizons" & 14 & 1.63 \\
\hline "Journal of Direct Data and Digital Marketing Practice" & 12 & 1.39 \\
\hline "Journal of Global Fashion Marketing" & 12 & 1.39 \\
\hline "Journal of Retailing and Consumer Services" & 12 & 1.39 \\
\hline "Online Information Review" & 12 & 1.39 \\
\hline "Sustainability Switzerland" & 12 & 1.39 \\
\hline "Lecture Notes in Business Information Processing" & 11 & 1.28 \\
\hline "Social Network Analysis and Mining" & 11 & 1.28 \\
\hline "Telematics and Informatics" & 11 & 1.28 \\
\hline "Journal of Interactive Marketing" & 10 & 1.16 \\
\hline "Marketing Intelligence and Planning" & 10 & 1.16 \\
\hline "European Journal of Marketing" & 9 & 1.05 \\
\hline
\end{tabular}

\subsection{Keywords analysis}

The keywords analysis is the most important method that derives the researcher to the author's documents. Social Media is the most frequent keyword used with a total of $9.16 \%$ and with the frequency of 731 times (see Table 5).

Table 5. Top 20 keywords

\begin{tabular}{|l|c|c|l|c|c|}
\hline \multicolumn{1}{|c|}{ Keywords } & Frequency & $\mathbf{\%}$ & \multicolumn{1}{c|}{ Keywords } & Frequency & \% \\
\hline Social Media & 731 & 9.16 & Twitter & 115 & 1.44 \\
\hline Facebook & 678 & 8.5 & Article & 111 & 1.39 \\
\hline Social Networking & 640 & 8.02 & Social Network & 111 & 1.39 \\
\hline Marketing & 615 & 7.71 & Advertising & 106 & 1.33 \\
\hline
\end{tabular}


Table 5. Top 20 keywords (continued)

\begin{tabular}{|l|c|c|l|c|c|}
\hline \multicolumn{1}{|c|}{ Keywords } & Frequency & $\mathbf{\%}$ & \multicolumn{1}{c|}{ Keywords } & Frequency & \% \\
\hline Commerce & 254 & 3.18 & SNS & 105 & 1.32 \\
\hline Human & 173 & 2.17 & Sales & 101 & 1.27 \\
\hline Social Networks & 147 & 1.84 & Data Mining & 78 & 0.98 \\
\hline Internet & 130 & 1.63 & Sentiment Analysis & 67 & 0.84 \\
\hline Humans & 122 & 1.53 & Adult & 66 & 0.83 \\
\hline Social Media Marketing & 119 & 1.49 & Social Media Marketings & 63 & 0.79 \\
\hline
\end{tabular}

\subsection{Geographical distribution of publications}

Table 6 displays the top 20 countries who contributed to the publications that indicates the volume of publications productivity through countries or regions. United States commands the top spot with $22.66 \%$ (523 publications). The $2^{\text {nd }}$ spot goes to India with $6.89 \%$ (159 publications).

Table 6. Top 20 countries contributed to the publications

\begin{tabular}{|l|c|c|l|c|c|}
\hline \multicolumn{1}{|c|}{ Country } & Frequency & $\mathbf{\%}$ & \multicolumn{1}{c|}{ Country } & Frequency & \% \\
\hline United States & 523 & 22.66 & Canada & 51 & 2.21 \\
\hline India & 159 & 6.89 & Italy & 46 & 1.99 \\
\hline United Kingdom & 141 & 6.11 & Indonesia & 39 & 1.69 \\
\hline Australia & 100 & 4.33 & France & 38 & 1.65 \\
\hline Germany & 90 & 3.9 & Thailand & 35 & 1.52 \\
\hline Taiwan & 88 & 3.81 & Portugal & 34 & 1.47 \\
\hline Spain & 84 & 3.64 & Czech Republic & 32 & 1.39 \\
\hline Malaysia & 61 & 2.64 & Brazil & 30 & 1.3 \\
\hline China & 57 & 2.47 & Greece & 27 & 1.17 \\
\hline South Korea & 54 & 2.34 & Netherlands & 27 & 1.17 \\
\hline
\end{tabular}

\subsection{Authorship}

The top 20 most productive authors is shown in Table 7. Two of the authors produced 7 documents each, another two authors produced 6 documents each, 9 authors produced 5 documents each and the rest of the authors produced 4 documents each. The cumulative percentage for the top 2 most productive authors consists $2.78 \%$ from the total 504 No. of Documents.

Table 7. Top 20 most productive authors

\begin{tabular}{|l|c|c|}
\hline \multicolumn{1}{|c|}{ Author's Name } & No. of Documents & \% \\
\hline Leung, X.Y. & 7 & 1.39 \\
\hline Weber, I. & 7 & 1.39 \\
\hline Leng, H.K. & 6 & 1.19 \\
\hline
\end{tabular}

(Continued) 
Table 7. Top 20 most productive authors (continued)

\begin{tabular}{|l|c|c|}
\hline \multicolumn{1}{|c|}{ Author's Name } & No. of Documents & \% \\
\hline Mislove, A. & 6 & 1.19 \\
\hline Alavi, S. & 5 & 0.99 \\
\hline Di Pietro, L. & 5 & 0.99 \\
\hline Fagerstrøm, A. & 5 & 0.99 \\
\hline Gummadi, K.P. & 5 & 0.99 \\
\hline Lee, W. & 5 & 0.99 \\
\hline Mejova, Y. & 5 & 0.99 \\
\hline Michahelles, F. & 5 & 0.99 \\
\hline Pantano, E. & 5 & 0.99 \\
\hline Yu, B. & 5 & 0.99 \\
\hline Ahuja, V. & 4 & 0.79 \\
\hline Baena, V. & 4 & 0.79 \\
\hline Chairat, S. & 4 & 0.79 \\
\hline Chen, Y.M. & 4 & 0.79 \\
\hline Homhual, P. & 4 & 0.79 \\
\hline Jaafar, N.I. & 4 & 0.79 \\
\hline Jansen, B.J. & 4 & 0.79 \\
\hline
\end{tabular}

\subsection{Citation analysis}

Citation analysis is the consideration upon patterns and frequency of citations in documents that link from one document to another. This is to reveal the properties of the documents. Table 8 shows the result for citation analysis which derived from Harzing's Publish or Perish software. Besides, the results of publication years, citation years, papers, citations, citations/year, citations/paper, authors/paper, h-index and g-index are also presented.

Table 8. Citations metrics

\begin{tabular}{|l|c|}
\hline \multicolumn{1}{|c|}{ Metrics } & Data \\
\hline Publication years & 2006-2020 \\
\hline Citation years & $14(2006-2020)$ \\
\hline Papers & 1888 \\
\hline Citations & 23479 \\
\hline Citations/year & 1677.07 \\
\hline Citations/paper & 12.44 \\
\hline Authors/paper & 2.83 \\
\hline h-index & 70 \\
\hline g-index & 116 \\
\hline
\end{tabular}


Table 9 indicates the top 20 highly cited articles considered as the most influential papers. Within the range of 1888 papers and 23479 citations, the highest number of cites is 679 , written by R. Hanna, A. Rohm, V.L. Crittenden with the title article of "We're all connected: The power of the social media ecosystem".

Table 9. Top 20 highly cited articles

\begin{tabular}{|c|c|c|c|c|c|}
\hline Ref. & Authors & Title & Year & Cites & $\begin{array}{c}\text { Cites } \\
\text { per Year }\end{array}$ \\
\hline 22 & $\begin{array}{l}\text { R. Hanna, A. Rohm, } \\
\text { V.L. Crittenden }\end{array}$ & $\begin{array}{l}\text { "We're all connected: The power of the } \\
\text { social media ecosystem" }\end{array}$ & 2011 & 679 & 75.44 \\
\hline 23 & $\begin{array}{l}\text { M. Cha, A. Mislove, } \\
\text { K.P. Gummadi }\end{array}$ & $\begin{array}{l}\text { "A measurement-driven analysis of } \\
\text { information propagation in the Flickr } \\
\text { social network" }\end{array}$ & 2009 & 548 & 49.82 \\
\hline 24 & $\begin{array}{l}\text { K.-Y. Goh, C.-S. } \\
\text { Heng, Z. Lin }\end{array}$ & $\begin{array}{l}\text { "Social media brand community and } \\
\text { consumer behavior: Quantifying the } \\
\text { relative impact of user- and marketer- } \\
\text { generated content" }\end{array}$ & 2013 & 523 & 74.71 \\
\hline 25 & $\begin{array}{l}\text { J.A. Greene, } \\
\text { N.K. Choudhry, } \\
\text { E. Kilabuk, } \\
\text { W.H. Shrank }\end{array}$ & $\begin{array}{l}\text { "Online social networking by patients } \\
\text { with diabetes: A qualitative evaluation of } \\
\text { communication with Facebook" }\end{array}$ & 2011 & 411 & 45.67 \\
\hline 7 & S. Aral, D. Walker & $\begin{array}{l}\text { "Creating social contagion through viral } \\
\text { product design: A randomized trial of peer } \\
\text { influence in networks" }\end{array}$ & 2011 & 368 & 40.89 \\
\hline 26 & $\begin{array}{l}\text { A.N. Smith, E. } \\
\text { Fischer, C. Yongjian }\end{array}$ & $\begin{array}{l}\text { "How does brand-related user-generated } \\
\text { content differ across YouTube, Facebook, } \\
\text { and Twitter?" }\end{array}$ & 2012 & 349 & 43.63 \\
\hline 27 & $\begin{array}{l}\text { W. Youyou, M. } \\
\text { Kosinski, D. } \\
\text { Stillwell }\end{array}$ & $\begin{array}{l}\text { "Computer-based personality judgments } \\
\text { are more accurate than those made by } \\
\text { humans" }\end{array}$ & 2015 & 293 & 58.6 \\
\hline 28 & M.M. Mostafa & $\begin{array}{l}\text { "More than words: Social networks' text } \\
\text { mining for consumer brand sentiments" }\end{array}$ & 2013 & 285 & 40.71 \\
\hline 17 & $\begin{array}{l}\text { K. Vance, W. Howe, } \\
\text { R.P. Dellavalle }\end{array}$ & $\begin{array}{l}\text { "Social internet sites as a source of public } \\
\text { health information" }\end{array}$ & 2009 & 255 & 23.18 \\
\hline 29 & $\begin{array}{l}\text { M.L. Antheunis, K. } \\
\text { Tates, T.E. Nieboer }\end{array}$ & $\begin{array}{l}\text { "Patients' and health professionals' use } \\
\text { of social media in health care: Motives, } \\
\text { barriers and expectations" }\end{array}$ & 2013 & 250 & 35.71 \\
\hline 30 & $\begin{array}{l}\text { I. Pletikosa, } \\
\text { F. Michahelles }\end{array}$ & $\begin{array}{l}\text { "Online engagement factors on Facebook } \\
\text { brand pages" }\end{array}$ & 2013 & 237 & 33.86 \\
\hline 31 & A. Hearn & $\begin{array}{l}\text { "Meat, mask, burden': Probing the } \\
\text { contours of the branded 'self"' }\end{array}$ & 2008 & 237 & 19.75 \\
\hline 18 & K. Heinonen & $\begin{array}{l}\text { "Consumer activity in social media: } \\
\text { Managerial approaches to consumers" } \\
\text { social media behavior" }\end{array}$ & 2011 & 227 & 25.22 \\
\hline 32 & $\begin{array}{l}\text { G.S. Enli, E. } \\
\text { Skogerbø }\end{array}$ & $\begin{array}{l}\text { "Personalized campaigns in party-centred } \\
\text { politics: Twitter and Facebook as arenas } \\
\text { for political communication" }\end{array}$ & 2013 & 221 & 31.57 \\
\hline
\end{tabular}

(Continued) 
Table 9. Top 20 highly cited articles (continued)

\begin{tabular}{|c|c|c|c|c|c|}
\hline Ref. & Authors & Title & Year & Cites & $\begin{array}{c}\text { Cites } \\
\text { per Year }\end{array}$ \\
\hline 8 & $\begin{array}{l}\text { M. Bruhn, V. } \\
\text { Schoenmueller, } \\
\text { D.B. Schäfer }\end{array}$ & $\begin{array}{l}\text { "Are social media replacing traditional } \\
\text { media in terms of brand equity creation?" }\end{array}$ & 2012 & 205 & 25.63 \\
\hline 33 & $\begin{array}{l}\text { M.S. Yadav, K. de } \\
\text { Valck, T. Hennig- } \\
\text { Thurau, D.L. } \\
\text { Hoffman, M. Spann }\end{array}$ & $\begin{array}{l}\text { "Social commerce: A contingency } \\
\text { framework for assessing marketing } \\
\text { potential" }\end{array}$ & 2013 & 181 & 25.86 \\
\hline 9 & $\begin{array}{l}\text { K. Hutter, J. Hautz, } \\
\text { S. Dennhardt, } \\
\text { J. Füller }\end{array}$ & $\begin{array}{l}\text { "The impact of user interactions in } \\
\text { social media on brand awareness and } \\
\text { purchase intention: The case of MINI on } \\
\text { Facebook" }\end{array}$ & 2013 & 179 & 25.57 \\
\hline 34 & $\begin{array}{l}\text { A. Kaplan, and } \\
\text { M. Haenlein }\end{array}$ & $\begin{array}{l}\text { "If you love something, let it go mobile: } \\
\text { Mobile marketing and mobile social } \\
\text { media } 4 \times 4 \text { " }\end{array}$ & 2012 & 168 & 21 \\
\hline 10 & A.J. Kim, E. Ko & $\begin{array}{l}\text { "Impacts of luxury fashion brand's social } \\
\text { media marketing on customer relationship } \\
\text { and purchase intention" }\end{array}$ & 2010 & 167 & 16.7 \\
\hline 35 & $\begin{array}{l}\text { E. Bonsón, S. Royo, } \\
\text { and M. Ratkai }\end{array}$ & $\begin{array}{l}\text { "Citizens' engagement on local } \\
\text { governments' Facebook sites: An } \\
\text { empirical analysis: The impact of } \\
\text { different media and content types in } \\
\text { Western Europe" }\end{array}$ & 2015 & 159 & 31.8 \\
\hline
\end{tabular}

\section{Discussion}

This study provided an overview of literature on Facebook Marketing for the years ranging between 2006 and 2020 by using bibliometric analysis of research productivity viewed through Scopus database. Within 1888 documents retrieved from Scopus, the document type of article tops the list with 1214 documents, equivalent to $64.3 \%$. Journal was the highest of source type with 1250 documents, equivalent to $66.21 \%$. The year 2019 tops the list for years of publications with 306 publications, equivalent to $16.21 \%$. The trend of publications increases from 2006 to 2019 , but decreases to 112 publications in 2020 . It is still too early to assume on the decreasing factors, as 2020 has only reached the early stage of the second quarter. This is due to current situations of the Covid-19 pandemic affects the trend of publications.

As for the language used, English language tops the list with 1843 documents published, equivalent to $97.36 \%$. This is fairly recognizable as to facilitate readers or other document researchers. The subject area that tops the list is Computer Science with a frequency of 775 , equivalent to $23.93 \%$. In conjunction with that, Lecture Notes in Computer Science Including Subseries Lecture Notes in Artificial Intelligence and Lecture Notes in Bioinformatics is the top active source title related to the study. As for the Citation Analysis, the article titled "We're all connected: The power of the social media ecosystem" tops the list with 679 citations. 


\section{Conclusion}

Bibliometric analysis approach was employed to review publication performances within the topic of Facebook Marketing. The total retrieved data of 1888 documents will be increasing as the year 2020 has just reached the early stage of second quarter. But, eventually, the documents would be added in a slow pace as the Covid-19 pandemic has struck the worldwide and has affected publication performances. Moreover, Facebook Marketing may not be as popular as Google marketing tools, in time to come. The limitations of the study can be identified as samples retrievable are more towards social media as a whole, but minimally on the specific area of Facebook Marketing. Future research is recommended to explore aspect of social networking as a tool related to business, economics and medical perspectives.

\section{$7 \quad$ Acknowledgement}

The financial support for this work was made available by the Geran Penjanaan of Universiti Utara Malaysia with SO Code: 14591.

\section{References}

[1] W. W. H. Cheng, E. T. H. Lam, and D. K. W. Chiu. (2020). Social media as a platform in academic library marketing: A comparative study. J. Acad. Libr.., 46(5), p. 102188. https:// doi.org/10.1016/j.acalib.2020.102188

[2] L. Iannelli, F. Giglietto, L. Rossi, and E. Zurovac. (2020). Facebook digital traces for survey research: Assessing the efficiency and effectiveness of a Facebook ad-based procedure for recruiting online survey respondents in niche and difficult-to-reach populations. Soc. Sci. Comput. Rev., 38(4), 462-476. https://doi.org/10.1177/0894439318816638

[3] H. Shahbaznezhad, R. Dolan, and M. Rashidirad. (2021). The role of social media content format and platform in users' engagement behavior. J. Interact. Mark., 53, 47-65. https://doi. org/10.1016/j.intmar.2020.05.001

[4] B. Light, K. McGrath, and M. Griffiths. (2008). More than just friends? Facebook, disclosive ethics and the morality of technology.

[5] R. Raskin. (2006). Facebook faces its future. Young Consum. Insight Ideas Responsible Mark., 7(2), 56-58. https://doi.org/10.1108/17473610610701493

[6] J. Hamilton. (2008). Approaches to customer-focused e-marketing. 198-204.

[7] S. Aral and D. Walker. (2011). Creating social contagion through viral product design: A randomized trial of peer influence in networks. Management Science, 57(9), 1623-1639. https://doi.org/10.1287/mnsc.1110.1421

[8] M. Bruhn, V. Schoenmueller, and D. B. Schäfer. (2012). Are social media replacing traditional media in terms of brand equity creation?. Management Research Review, 35, 770-790. https://doi.org/10.1108/01409171211255948

[9] K. Hutter, J. Hautz, S. Dennhardt, and J. Füller. (2013). The impact of user interactions in social media on brand awareness and purchase intention: The case of MINI on Facebook. Journal of Product \& Brand Management, 22, 342-351. https://doi.org/10.1108/ JPBM-05-2013-0299 
[10] A. J. Kim and E. Ko. (2010). Impacts of luxury fashion brand's social media marketing on customer relationship and purchase intention. J. Glob. Fashion Mark., 1(3), 164-171. https://doi.org/10.1080/20932685.2010.10593068

[11] K. Swani, G. Milne, and B. P. Brown. (2013). Spreading the word through likes on Facebook: Evaluating the message strategy effectiveness of Fortune 500 companies. Journal of Research in Interactive Marketing, 7(4), 269-294. https://doi.org/10.1108/JRIM-05-2013-0026

[12] L. Kwok and B. Yu. (2013). Spreading social media messages on Facebook: An analysis of restaurant business-to-consumer communications. Cornell Hospitality Quarter-ly, 54(1), 84-94. https://doi.org/10.1177/1938965512458360

[13] Y.-T. Chang, H. Yu, and H.-P. Lu. (2015). Persuasive messages, popularity cohesion, and message diffusion in social media marketing. J. Bus. Res., 68(4), 777-782. https://doi. org/10.1016/j.jbusres.2014.11.027

[14] F. Sabate, J. Berbegal-Mirabent, A. Cañabate, and P. R. Lebherz. (2014). Factors influencing popularity of branded content in Facebook fan pages. European Management Journal, 32(6), 1001-1011. https://doi.org/10.1016/j.emj.2014.05.001

[15] J. Kang, L. Tang, and A. M. Fiore. (2014). Enhancing consumer-brand relationships on restaurant Facebook fan pages: Maximizing consumer benefits and increasing active participation. Int. J. Hosp. Manag., 36, 145-155. https://doi.org/10.1016/j.ijhm.2013.08.015

[16] W. He, H. Wu, G. Yan, V. Akula, and J. Shen. (2015). A novel social media competitive analytics framework with sentiment benchmarks. Inf. Manag., 52(7), 801-812. https://doi. org/10.1016/j.im.2015.04.006

[17] K. Vance, W. Howe, and R. P. Dellavalle. (2009). Social internet sites as a source of public health information. Dermatol. Clin., 27(2), 133-6. https://doi.org/10.1016/j.det.2008.11.010

[18] K. Heinonen. (2011). Consumer activity in social media: Managerial approaches to consumers' social media behavior: Consumer activity in social media. J. Consum. Behav., 10(6), 356-364. https://doi.org/10.1002/cb.376

[19] F. Parveen, N. I. Jaafar, and S. Ainin. (2015). Social media usage and organizational performance: Reflections of Malaysian social media managers. Telemat. Inform., 32(1), 67-78. https://doi.org/10.1016/j.tele.2014.03.001

[20] G. Ahamer and K. A. Kumpfmüller. (2014). Education and literature for development in responsibility: Partnership hedges globalization. IGI Global, 526-584. https://doi. org/10.4018/978-1-4666-4458-8.ch027

[21] M. K. McBurney and P. L. Novak. (2003). What is bibliometrics and why should you care? in Proceedings. IEEE International Professional Communication Conference.

[22] R. Hanna, A. Rohm, and V. L. Crittenden. (2011). We're all connected: The power of the social media ecosystem. Bus. Horiz., 54(3), 265-273. https://doi.org/10.1016/j. bushor.2011.01.007

[23] M. Cha, A. Mislove, and K. P. Gummadi. (2009). A measurement-driven analysis of information propagation in the Flickr social network. 721-730. https://doi. org/10.1145/1526709.1526806

[24] K.-Y. Goh, C.-S. Heng, and Z. Lin. (2013). Social media brand community and consumer behavior: Quantifying the relative impact of user- and marketer-generated content. Information Systems Research, 24(1), 88-107. https://doi.org/10.1287/isre.1120.0469

[25] J. A. Greene, N. K. Choudhry, E. Kilabuk, W. H. Shrank. (2010). Online social networking by patients with diabetes: A qualitative evaluation of communication with Facebook. Journal of General Internal Medicine, 26(3), 287-292. https://doi.org/10.1007/s11606-010-1526-3

[26] A. N. Smith, E. Fischer, and C. Yongjian. (2012). How does brand-related user-generated content differ across YouTube, Facebook, and Twitter?. Journal of Interactive Marketing, 26(2), 102-113. https://doi.org/10.1016/j.intmar.2012.01.002

[27] W. Youyou, M. Kosinski, and D. Stillwell. (2015). Computer-based personality judgments are more accurate than those made by humans. Proc. Natl. Acad. Sci. U. S. A., 112(4), 1036-1040. https://doi.org/10.1073/pnas.1418680112 
[28] M. M. Mostafa. (2013). More than words: Social networks' text mining for consumer brand sentiments. Expert Syst. Appl., 40(10), 4241-4251. https://doi.org/10.1016/j. eswa.2013.01.019

[29] M. L. Antheunis, K. Tates, and T. E. Nieboer. (2013). Patients' and health professionals' use of social media in health care: Motives, barriers and expectations. Patient Education and Counseling, 92(3), 426-431. https://doi.org/10.1016/j.pec.2013.06.020

[30] I. Pletikosa, and F. Michahelles. (2013). Online engagement factors on Facebook brand pages. Social Network Analysis and Mining, 3(4), 843-861. https://doi.org/10.1007/ s13278-013-0098-8

[31] A. Hearn. (2008). Meat, mask, burden: Probing the contours of the brandedself. Journal of Consumer Culture, 8(2), 197-217. https://doi.org/10.1177/1469540508090086

[32] G. S. Enli and E. Skogerbø. (2013). Personalized campaigns in party-centred politics: Twitter and Facebook as arenas for political communication. Inf. Commun. Soc., 16(5), 757-774. https://doi.org/10.1080/1369118X.2013.782330

[33] M. S. Yadav, K. de Valck, T. Hennig-Thurau, D. L. Hoffman, and M. Spann. (2013). Social commerce: A contingency framework for assessing marketing potential. Journal of Interactive Marketing, 27(4), 311-323. https://doi.org/10.1016/j.intmar.2013.09.001

[34] A. Kaplan, and M. Haenlein. (2012). If you love something, let it go mobile: Mobile marketing and mobile social media 4x4. Bus. Horiz., 55(2), 129-139. https://doi.org/10.1016/j. bushor.2011.10.009

[35] E. Bonsón, S. Royo, and M. Ratkai. (2015). Citizens' engagement on local governments' Facebook sites: An empirical analysis: The impact of different media and content types in Western Europe. Government Information Quarterly, 32(1), 52-62. https://doi.org/10.1016/j. giq.2014.11.001

[36] S. Rautela. (2021). Social Media for New Product Launch: A Study of Social Media Platforms Across the RACE Planning Framework. International Journal of Interactive Mobile Technologies, 15(5), 187-204. https://doi.org/10.3991/ijim.v15i05.18147

[37] H. Zanuddin, and N. Shaid. (2021). Social Perceived Value on Social Media and Online News Portal. International Journal of Interactive Mobile Technologies, 15(4), 61-72. https:// doi.org/10.3991/ijim.v15i04.20189

\section{Authors}

Nadzrif Othman is currently an MBA student at Othman Yeop Abdullah Graduate School of Business, Universiti Utara Malaysia, Kedah, Malaysia. His areas of interest include business management, marketing, international marketing and consumer behaviour. email: nadzrif@gmail.com

Assoc. Prof. Dr. Norbayah Mohd Suki is an Associate Professor at School of Creative Industry Management \&amp; Performing Arts, Universiti Utara Malaysia, Kedah, Malaysia. Her research interests include Creative Multimedia, Mobile Learning, Animation, HCI, User Experience and Behaviour, etc. She can be reached at bayasuki@yahoo.com.

Professor Dr. Norazah Mohd Suki is a Professor of Marketing \& E-Commerce at Othman Yeop Graduate School of Business (OYAGSB), Universiti Utara Malaysia. Her research interests include Marketing and E-Commerce. She can be contacted at: azahsuki@yahoo.com.

Article submitted 2021-04-30. Resubmitted 2021-06-29. Final acceptance 2021-06-29. Final version published as submitted by the authors. 